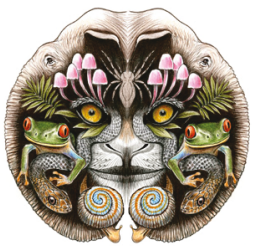

ISSN 0974-7907 (Online) ISSN 0974-7893 (Print)

OPEN ACCESS

\title{
SMALL CARNIVORES OF BILIGIRI RANGASWAMY TEMPLE TIGER RESERVE, KARNATAKA, INDIA
}

\begin{abstract}
Honnavalli N. Kumara ${ }^{1}$, Ovee Thorat ${ }^{2}$, Kumar Santhosh ${ }^{3}$, R. Sasi ${ }^{4}$ \& H.P. Ashwin ${ }^{5}$
1,3 Sálim Ali Centre for Ornithology and Natural History, Anaikatty (PO), Coimbatore, Tamil Nadu 641108, India

B/502, Atlanta CHS LTD, Mithagar Road, Kandarpada, Dahisar (West), Mumbai, Maharashtra 400068, India ${ }^{2}$ Current Address: Ashoka Trust for Research in Ecology and the Environment, Royal Enclave, Sriramapura, Jakkur Post, Bengaluru, Karnataka 560064, India

${ }^{4}$ Department of Anthropology, University of Madras, Chepauk Campus, Chennai, Tamil Nadu 600005, India

${ }^{5}$ No. $2434,1^{\text {st }}$ Cross, Hosabandikeri, Near Nanjumligai Circle, K.R. Mohalla, Mysuru, Karnataka 570024, India Current address: ${ }^{5}$ Nature Conservation Foundation, 3076/5, IV cross, Gokulam Park, Mysuru, Karnataka 570002, India

${ }^{1}$ honnavallik@gmail.com (corresponding author), ${ }^{2}$ ovthorat@gmail.com, ${ }^{3}$ bearsanthosh@gmail.com, ${ }^{4}$ sasi2882@gmail.com, ${ }^{5}$ ashwinbubo@gmail.com
\end{abstract}

Abstract: During the present study in Biligiri Rangaswamy Temple Tiger Reserve (BRT), nine species of small carnivores viz., Jungle Cat Felis chaus, Rusty-spotted Cat Prionalilurus rubiginosus, Leopard Cat Prionailurus bengalensis, Small Indian Civet Viverricula indica, Asian Palm Civet Paradoxurus hermaphroditus, Striped-necked Mongoose Herpestes vitticollis, Ruddy Mongoose Herpestes smithii, Common Mongoose Herpestes edwardsii and Smooth-coated Otter Lutrogale perspicillata, were recorded using camera-trapping technique, transect walks, and night surveys. Vegetation type strongly influences the presence and abundance of each species. The most sightings of small carnivores occurred in dry deciduous forests. Among all the species, the Asian Palm Civet was the most abundant and was followed by the small Indian Civet. Compared to many other forests or regions in India, the sight records of the Rusty-spotted Cat were relatively higher in BRT. Although we were unable to use statistical methods to search for higher levels of interdependencies between forest types and small carnivore abundance, our study sheds light on patterns of small carnivore distribution in this unique habitat which bridges the Western Ghats and the Eastern Ghats.

Keywords: Abundance, BRT Tiger Reserve, camera trapping, line transects, small carnivores, vehicular survey.
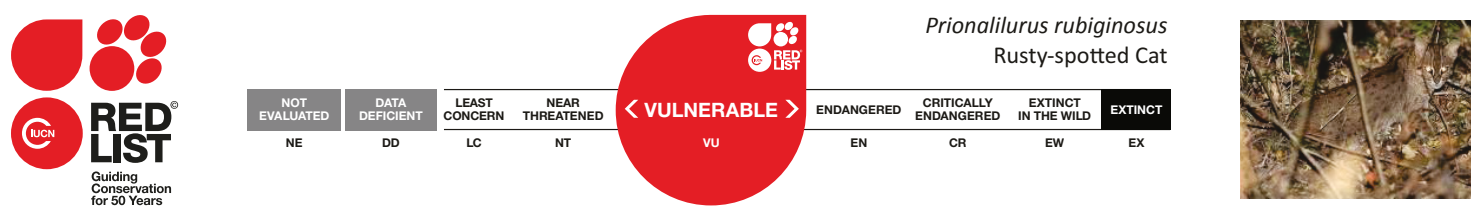

DOI: http://dx.doi.org/10.11609/JoTT.o3766.6534-43 | ZooBank: urn:Isid:zoobank.org:pub:00F19FED-31FE-4691-AC5D-93B60CE4DBD2

Editor: P.O. Nameer, Kerala Agricultual University, Thrissur, India.

Date of publication: 26 November 2014 (online \& print)

Manuscript details: Ms \# 03766 | Received 13 September 2013 | Final received 31 October 2014 | Finally accepted 03 November 2014

Citation: Kumara, H.N., O. Thorat, K. Santhosh, R. Sasi \& H.P. Ashwin (2014). Small carnivores of Biligiri Rangaswamy Temple Tiger Reserve, Karnataka, India. Journal of Threatened Taxa 6(12): 6534-6543; http://dx.doi.org/10.11609/JoTT.03766.6534-43

Copyright: () Kumara et al. 2014. Creative Commons Attribution 4.0 International License. JoTT allows unrestricted use of this article in any medium, reproduction and distribution by providing adequate credit to the authors and the source of publication.

Funding: This project was funded by Karnataka Forest Department (D/WL/CR-12/2010-2011. Dated:21 August 2010).

Competing Interest: The authors declare no competing interests.

Acknowledgements: We thank the Principal Chief Conservator of Forests Mr. B.K. Singh and Mr. Deepak Sharma for encouragement and constant support for the study. Thanks are also due to Mr. Shekar, Mr. Bishwajith Mishra and Mr. Vijay Mohan Raj for their constant support and encouragement; Mr. Sridhar, Mr. Boraiah, Mr. Nataraj and Mr. Sridhar RFOs of the park for their support in the field; all the forest personnel for spending time, walking transects, helping us finding the proper location for camera deployment, sharing their experiences about the wild animals, and for providing us with constant support during the entire study; Dr. P.A. Azeez, SACON for the constant support and encouragement. We acknowledge the support of Mr. Nikhil, Mr. Sapthagirish, Mr. Kumar, Mr. Chidanand for volunteering for the field work and Madeva Gowda for sharing local knowledge which helped us to complete the study.
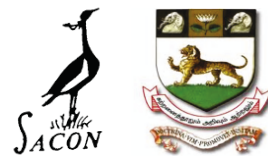
The Biligiri Rangaswamy Temple Tiger Reserve (BRT) is known to be a crucial link between two hill systems in southern India, the Eastern Ghats and the Western Ghats (Ganeshaiah \& Shankar 1998). BRT is part of the Nilgiri Biosphere Reserve (NBR), which is one of the largest stretches of contiguous forests in southern India and holds rich flora and fauna due to the high variation of altitude and wide array of vegetation types. The wide range of climatic conditions also contributes to heterogeneous assemblage of forest types such as scrub, deciduous, riparian, evergreen forests, and the shola forests.

In peninsular India, very few studies have documented the ecological aspects of small carnivore species (Mukherjee 1989; Mudappa 2001; Rajamani et al. 2003; Mukherjee et al. 2004). Apart from these detailed studies, much of the information on some of the species comes from anecdotal, sight records and some systematic surveys using different methods, which have significantly contributed to understanding their distribution and status.

Diverse topics related to flora, forest structure and forest-people interactions in BRT have been well addressed by various studies (Ramesh 1989; Hegde et al. 1996; Murali et al. 1996, 1998; Ganeshaiah et al. 1998; Bawa et al. 1999; Shankar et al. 1996; Shanker 1998, 2004; Murali \& Setty 2001; Setty et al. 2001; Ganesan \& Setty 2004) and sight records of birds and their importance have been reported from the landscape (Karthikeyan et al. 1995; Aravind et al. 2001; Islam \& Rahmani 2004, Srinivasan \& Prashanth 2005, 2006). A list of various fauna (major taxa) in BRT was compiled by Zoological Survey of India, Kolkata (Anonymous 2006). However, there has been no proper documentation on any aspect of mammals. A study was therefore conducted between 2009 and 2011 to establish baseline information on the occurrence, abundance and distribution of mammals in BRT (Kumara et al. 2012a,b). In the present article, we report the occurrence and distribution of small carnivores in relation to forest types.

\section{MATERIALS AND METHOdS}

Biligiri Rangaswamy Temple Tiger Reserve is in Chamarajnagar District of Karnataka and lies between $11^{\circ} 40^{\prime}-12^{\circ} 09^{\prime} \mathrm{N} \& 77^{\circ} 05^{\prime}-77^{\circ} 15^{\prime} \mathrm{E}$, covering an area of $610 \mathrm{~km}^{2}$ (Fig. 1). Biogeographically, the area is located at the easternmost edge of the Western Ghats between $11^{\circ} \mathrm{N}$ and $12^{\circ} \mathrm{N}$. Its north-south ranges meet the hills of the Eastern Ghats at $78^{\circ} \mathrm{E}$ thus forming a bridge between the Western and the Eastern Ghats. The altitude varies from $600-1800 \mathrm{~m}$. Forest types in the study site include scrub forests at the foot hills, deciduous forests on the hill slopes with an altitude between $500-1000 \mathrm{~m}$, riparian and moist deciduous forests at mid elevation, and evergreen forests and the shola grasslands at higher elevations (above $1200 \mathrm{~m}$ ).

\section{Survey methods}

Surveys were conducted at all times of the day in order to record both diurnal and nocturnal species. While the line transect method of sampling was used to record diurnal species, searches along forest paths were conducted by night. Additionally, camera traps were deployed to validate detections of elusive species.

Transect walk: A total of 33 random line transects representing all the forest types, altitudinal gradients and administrative units of the sanctuary were marked in the study area. The length of transects was kept between 2-4 $\mathrm{km}$ (totaling $93 \mathrm{~km}$ ) based on the terrain and vegetation type and each transect was walked a minimum of five times and maximum of 11 times between 06.00 to 10.00 $\mathrm{hr}$ and 16.30 to $18.30 \mathrm{hr}$. Transects were walked during a period of seven months from October 2009 to April 2010, totaling $795.5 \mathrm{~km}$. During the transect walk, for every sighting of the animal, data related to the name of the species, the number of individuals, the animal to observer distance and the angle of the detection from the main bearing were collected. The coordinates were recorded for each sighting using GARMIN eTrex $\mathrm{H}$ and GARMIN 72 GPS units. Species identification was made using Prater (1971) and Menon (2003).

Night surveys: We selected existing motorable roads and each road was traveled consecutively for two days between 19.00-24.00 hr. A four wheel drive vehicle was driven at the speed of $10 \mathrm{~km} / \mathrm{hr}$, an observer sitting atop beaming a flash light to sight nocturnal animals (Kumara et al. 2006; Kumara \& Singh 2007). When an animal was spotted with eyes shining, it was identified by using binoculars. The distance covered was documented using the vehicle odometer or with the known distance of each route. The abundance of nocturnal animals was presented as an encounter rate (animals $/ \mathrm{km}$ ). A total of $462 \mathrm{~km}$ of sampling was done during the night surveys.

Camera-trapping: A two sq. km. grid layer was overlaid on the area of the entire reserve. The mid-region of BRT is highly elevated and rugged while the foothills consist of scrub or dry deciduous forests. In order to have an equal representation of all forest types, alternate grids from west to east were selected for sampling. A total of 41 grids were sampled between September 2010 and December 2011, and in each grid, 9-10 camera traps were deployed at regular intervals at the rate of one trap per 20ha. Camera traps were left for one day 


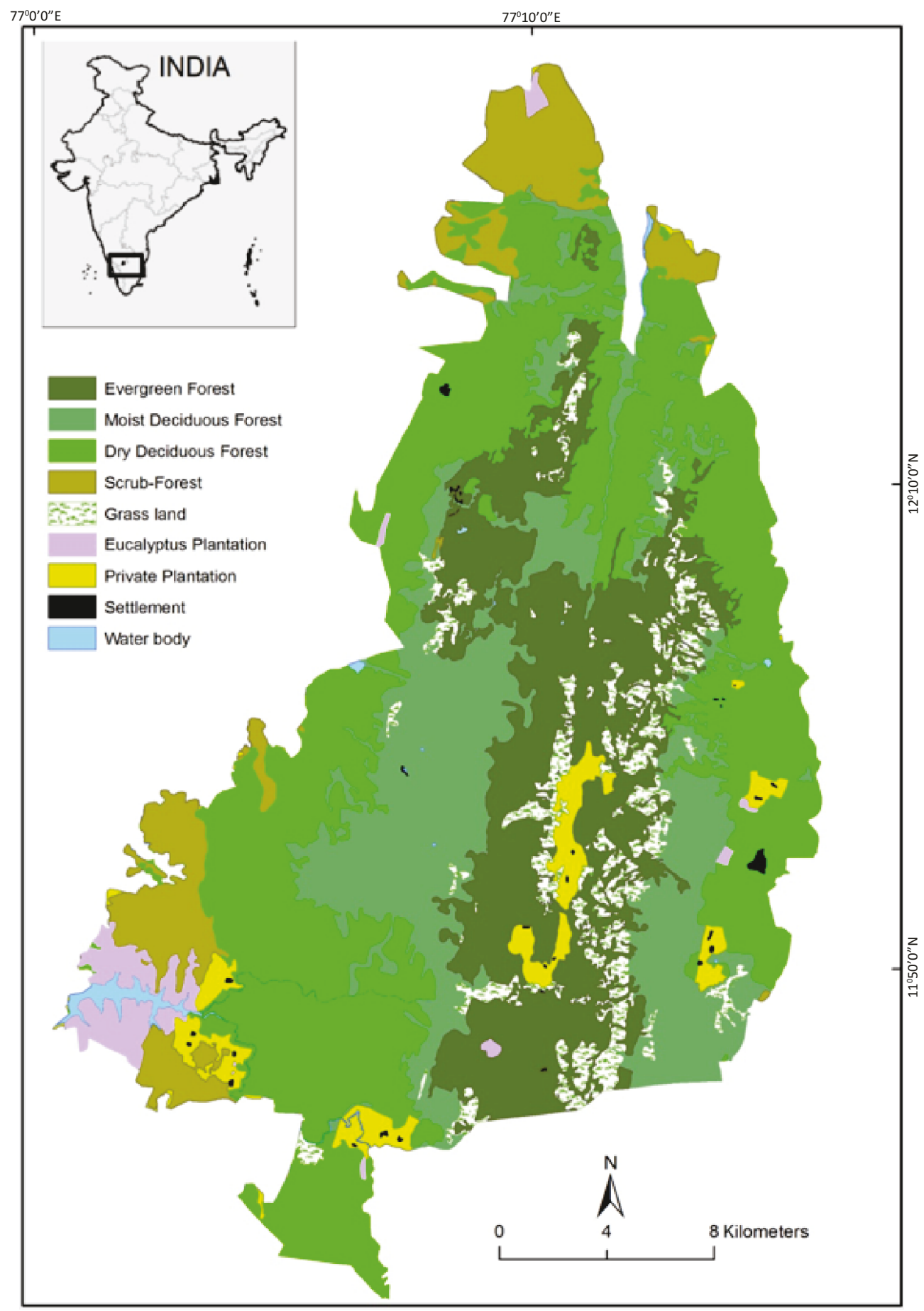

Figure 1. Location and forest types of Biligiri Ranganathaswamy Temple Tiger Reserve

(24 hours) in each site with a dry fish bait to lure the animals towards the traps to increase the detection rate. However, because they were trampled on by elephants or due to malfunctioning of the camera traps, the number of camera trap nights was only 328. We used passive infrared digital camera traps, with a battery backup for 10 days and a 4GB memory card. It has been shown earlier that digital cameras out-perform film cameras, and that passive cameras have higher success when compared to active cameras (Kelly \& Holub 2008). The locations of the traps were fixed based on the recent usage of the area by the animals, which was decided based on the animal trails or tracks showing recent movement of animals, proximity to old scats, or den sites. Undergrowth just below the 
camera was cleared using hand or machete to minimize false triggers. The cameras were placed approximately $50 \mathrm{~cm}$ above ground and were angled according to the slope. The images were downloaded with specific identity of the grids and geo-coordinates.

All sightings of small carnivore species were recorded with the details on species identity, number of individuals, location of sighting and vegetation type during the surveys. Detections of all the species from all the abovedescribed methods were used for the analysis and for creating a map to identify forests where small carnivore species commonly occurred. The data from night surveys gave an estimate of abundance (encounter rate) for the Small Indian Civet, the Asian Palm Civet, the Jungle Cat, the Leopard Cat and the Rusty-spotted Cat, whereas the data from day transects gave an estimate for the Common Mongoose, the Ruddy Mongoose and the Stripe-necked Mongoose. We did not sample the Smooth-coated Otter, as it requires a different field technique to assess relative abundance due to its habitat use. Detection being very less for many species, we could not estimate the abundance for any species. We computed the encounter rate for each species and represented them as the number of sightings per km.

\section{RESULTS}

During the study, nine species of small carnivores were recorded from BRT (Table 1). The sightings included two species listed as Vulnerable in IUCN Red List-the Rusty-Spotted Cat and the Smooth-coated Otter. A total of 126 sight records of small carnivores were made during the study span using various field techniques, among which night surveys yielded 87 sight records (69\% of the total records) considerably more than the other two techniques. Camera traps yielded relatively fewer records than day transects and night surveys, however, all the species were recorded by the cameras except the Leopard Cat. The mongoose species being largely diurnal were recorded during the day transects and by using the camera traps, whereas the nocturnal species like the small cats and civets were recorded during night surveys as well as by using camera traps.

In BRT, the relative abundance of the Ruddy Mongoose $(0.011 / \mathrm{km}, \mathrm{N}=9)$ was more than the Common Mongoose $(0.008 / \mathrm{km}, \mathrm{N}=6)$ and Stripe-necked Mongoose $(0.009 / \mathrm{km}, \mathrm{N}=7)$ (day transect walk, Table 1$)$, whereas the relative abundance of the Rusty-spotted Cat (0.024/ $\mathrm{km}, \mathrm{N}=11)$ was more than the Leopard Cat $(0.006 / \mathrm{km}$, $\mathrm{N}=3$ ) and Jungle Cat $(0.009 / \mathrm{km}, \mathrm{N}=4)$ (night survey, Table 1). Among civets, the abundance of the Asian Palm Civet (0.095) was more than the Small Indian Civet (0.054) (night survey, Table 1). Overall, the two civet species were the predominant species among all the small carnivore species. Otters were restricted to reservoirs around the park especially at Suvarnavathi and Gundal dams. Opportunistic sightings of two animals at Gundal and two to three animals at Suvarnavathi Dam were recorded.

The sightings of small carnivore species were more in the dry deciduous forests (38.52\%), followed by moist deciduous forests (28.68\%), evergreen forests (27.00\%) and scrub forest (5.74\%) (Table 2). Some of the species showed a restricted distribution pattern or high preference for certain vegetation types, e.g., the leopard cat was recorded only from evergreen forests whereas the Jungle Cat and Rusty-spotted Cat were recorded only from moist and deciduous forests (Fig. 2). Though both the civets were recorded from all the vegetation types, the Asian Palm Civet was almost equally recorded from all vegetation types except in the scrub forests, whereas the records of the Small Indian Civet was high for the dry

Table 1. Number of detections and relative abundance of small carnivores in different methods in BRT.

\begin{tabular}{|c|c|c|c|c|c|c|}
\hline Species & $\begin{array}{l}\text { IUCN } \\
\text { status }\end{array}$ & $\begin{array}{c}\text { Day transect } \\
\text { walk }(795.5 \mathrm{~km})\end{array}$ & $\begin{array}{l}\text { Night survey } \\
(462 \mathrm{~km})\end{array}$ & $\begin{array}{c}\text { Camera trap (328 } \\
\text { camera nights) }\end{array}$ & Opportunistic & Total \\
\hline Jungle Cat Felis chaus (Image 5) & LC & 0 & $4(0.009)$ & $1(0.003)$ & 0 & 5 \\
\hline Leopard Cat Prionailurus bengalensis (Image 6) & LC & 0 & $3(0.006)$ & 0 & 0 & 3 \\
\hline Rusty-spotted Cat Prionailurus rubiginosus (Image 7) & VU & 0 & $11(0.024)$ & $1(0.003)$ & 1 & 13 \\
\hline Small Indian Civet Viverricula indica (Images 1,2) & LC & 0 & $25(0.054)$ & $2(0.006)$ & 0 & 27 \\
\hline Asian Palm Civet Paradoxurus hermaphroditus (Images 3,4 ) & LC & 0 & $44(0.095)$ & $3(0.009)$ & 0 & 47 \\
\hline Stripe-necked Mongoose Herpestes vitticollis (Images 11,12) & LC & $7(0.009)$ & 0 & $3(0.009)$ & 0 & 10 \\
\hline Common Mongoose Herpestes edwardsi (Images 8,9) & LC & $6(0.008)$ & 0 & $2(0.006)$ & 0 & 8 \\
\hline Ruddy Mongoose Herpestes smithii (Image 10) & LC & $9(0.011)$ & 0 & $1(0.003)$ & 0 & 10 \\
\hline Smooth-coated Otter Lutrogale perspicillata & VU & - & - & - & 3 & 3 \\
\hline Total & & $22(0.03)$ & $87(0.19)$ & $13(0.04)$ & 4 & 126 \\
\hline
\end{tabular}



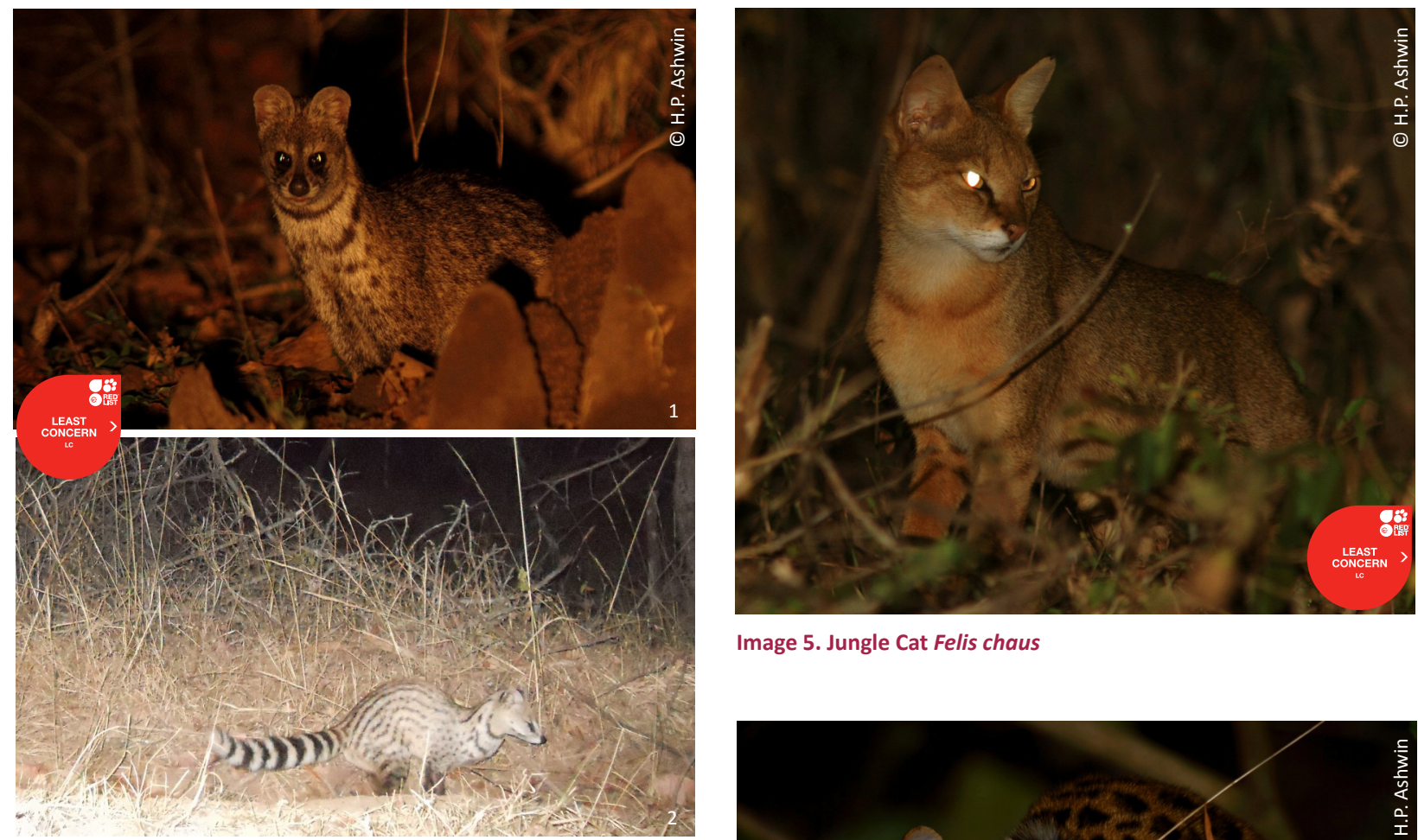

Image 5. Jungle Cat Felis chaus

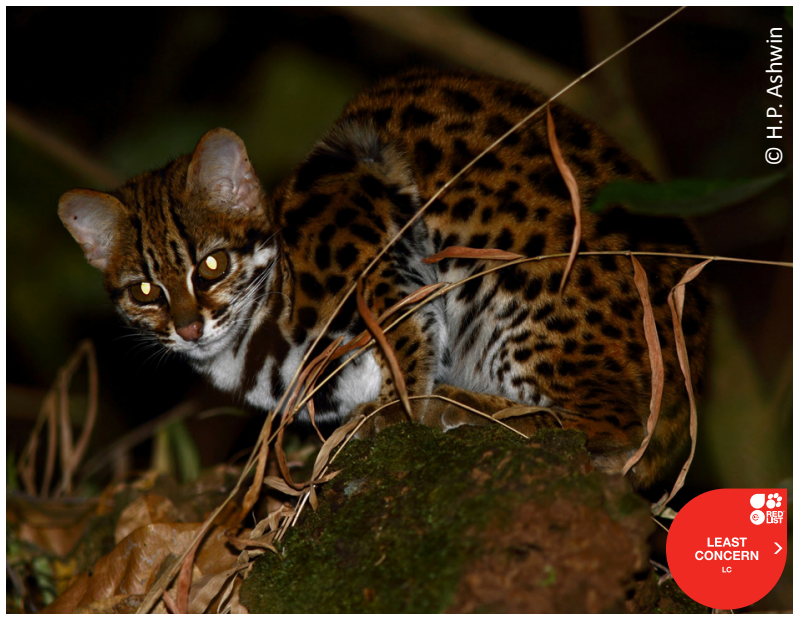

Image 6. Leopard Cat Prionailurus bengalensis

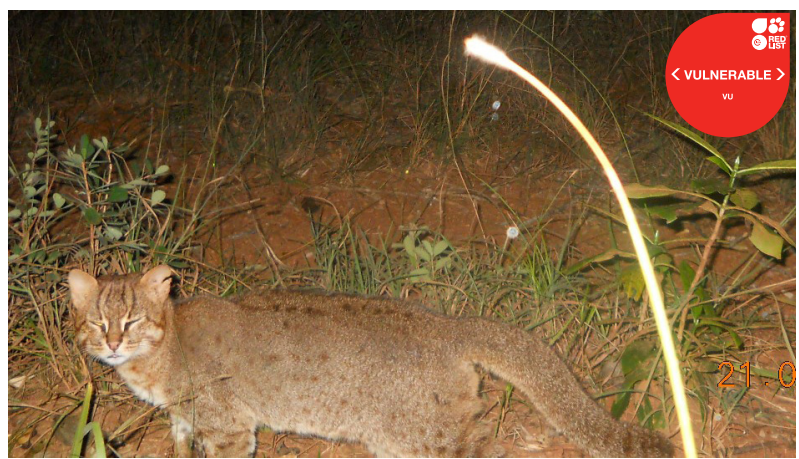

Image 7. Rusty-spotted Cat Prionalilurus rubiginosus

deciduous forests compared to the other forest types (Fig. 3). Among the three mongooses, the common mongoose was sighted more commonly in dry forests than the other

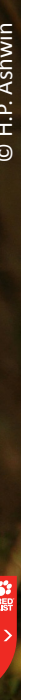

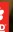
$>$

Images 1-2. Small Indian Civet Viverricula indica

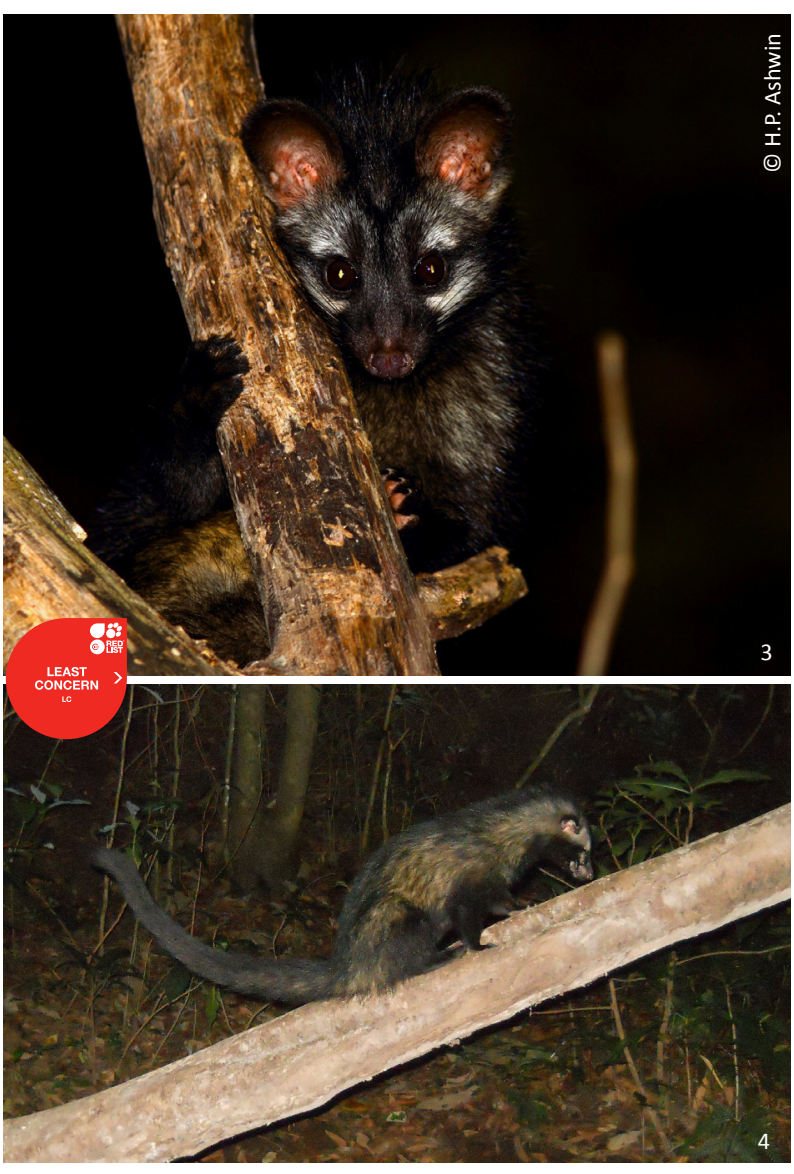

Images 3-4. Asian Palm Civet Paradoxurus hermaphroditus 


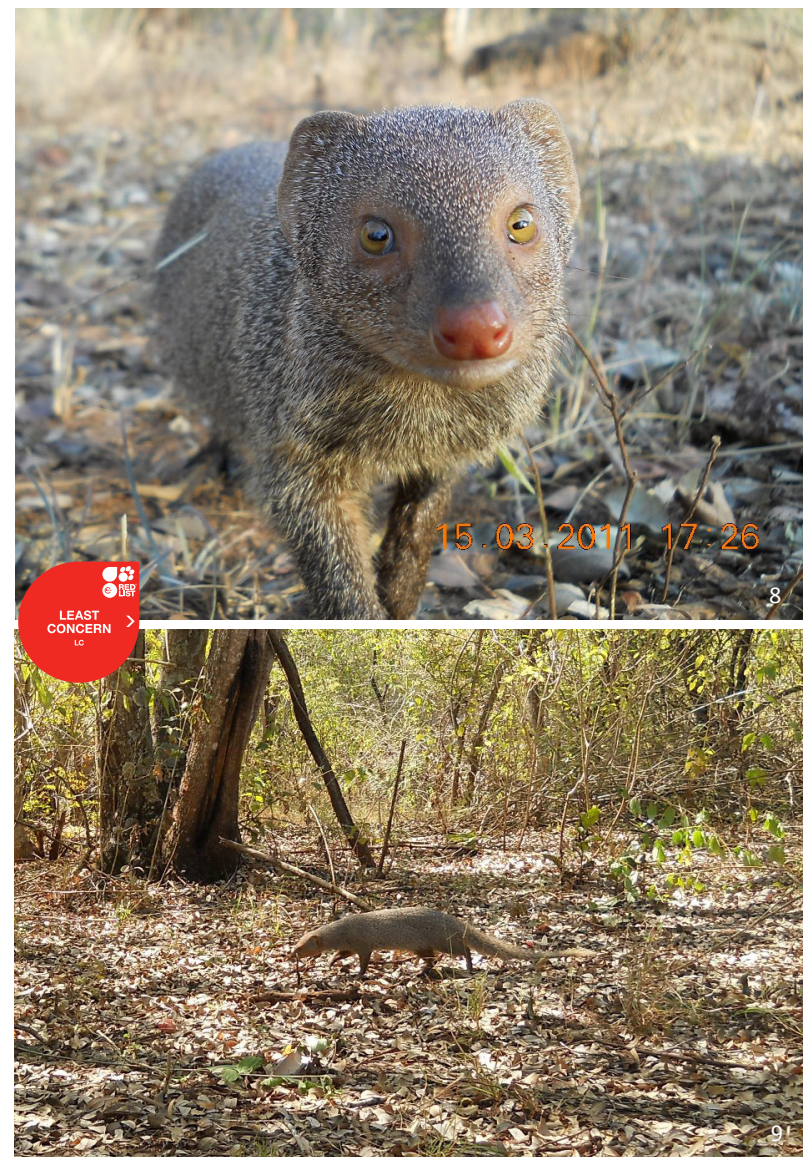

Images 8-9. Common Mongoose Herpestes edwardsii

two species, whereas the ruddy mongoose was sighted more commonly in the moist forests than in the dry forests (Fig. 4).

\section{Discussion}

The use of multiple methods could work better for studying the presence and distribution of elusive small carnivore species. The capture rate by camera trap technique may depend on the selection of the location to deploy the camera trap, the number of traps and camera trap nights per sampling area (Nag 2008). The selection of the number of traps per sampling area may be based

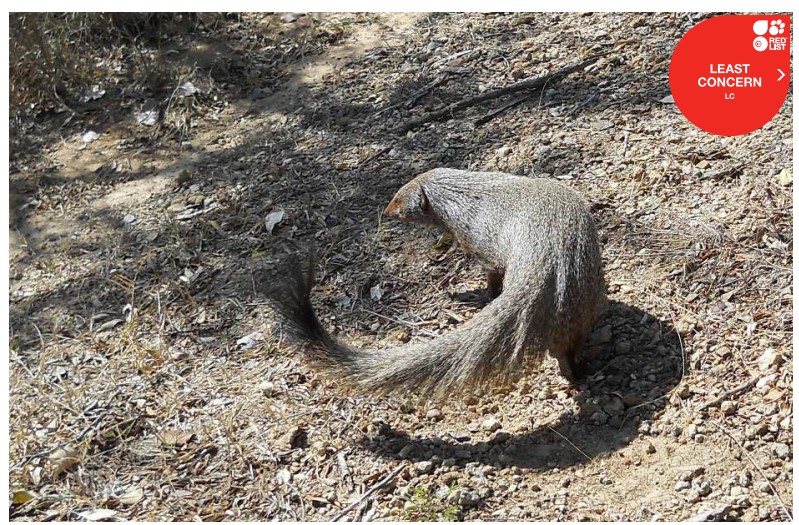

Image 10. Ruddy Mongoose Herpestes smithii

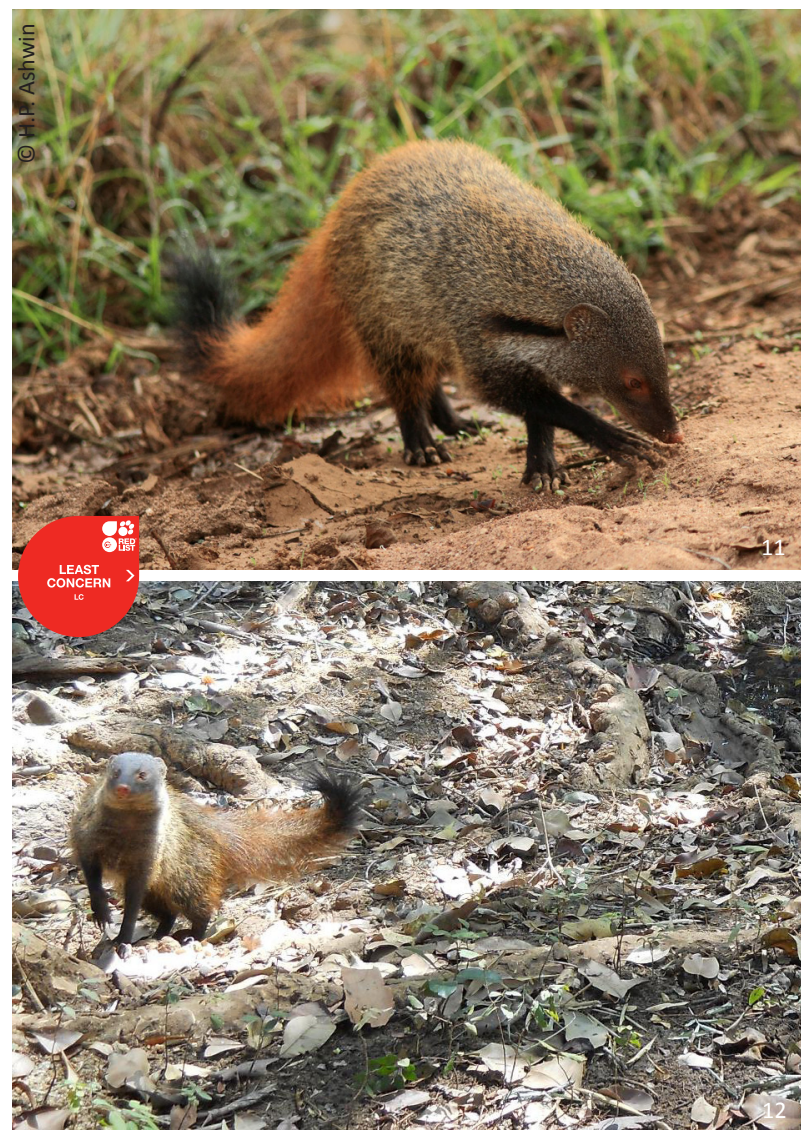

Images 11-12. Striped-necked Mongoose Herpestes vitticollis

Table 2. Proportion of detections in different vegetation type in BRT

\begin{tabular}{|c|c|c|c|c|c|c|c|c|c|}
\hline $\begin{array}{l}\text { Vegetation } \\
\text { type }\end{array}$ & $\begin{array}{l}\text { Jungle } \\
\text { Cat (\%) }\end{array}$ & $\begin{array}{l}\text { Leopard } \\
\text { Cat (\%) }\end{array}$ & $\begin{array}{l}\text { Rusty-spotted } \\
\text { Cat (\%) }\end{array}$ & $\begin{array}{l}\text { Asian Palm } \\
\text { Civet (\%) }\end{array}$ & $\begin{array}{l}\text { Small Indian } \\
\text { Civet (\%) }\end{array}$ & $\begin{array}{l}\text { Common } \\
\text { Mongoose (\%) }\end{array}$ & $\begin{array}{l}\text { Stripe-necked } \\
\text { Mongoose (\%) }\end{array}$ & $\begin{array}{l}\text { Ruddy } \\
\text { Mongoose (\%) }\end{array}$ & $\begin{array}{l}\text { Total } \\
\text { (\%) }\end{array}$ \\
\hline EG & 0 & $3(100.00)$ & 0 & $16(34.04)$ & $7(25.93)$ & 0 & $1(10.00)$ & $6(60.00)$ & $33(27.00)$ \\
\hline MDF & $2(40.00)$ & 0 & $3(23.08)$ & $15(31.91)$ & $8(29.63)$ & $1(12.50)$ & $5(50.00)$ & $2(20.00)$ & $36(28.68)$ \\
\hline DDF & $3(60.00)$ & 0 & $10(76.92)$ & $15(31.91)$ & $11(40.74)$ & $3(37.90)$ & $4(40.00)$ & $1(10.00)$ & $47(38.52)$ \\
\hline Scrub & 0 & 0 & 0 & $1(2.13)$ & $1(3.70)$ & $4(50.00)$ & 0 & $1(10.00)$ & $7(5.74)$ \\
\hline Total & 5 & 3 & 13 & 47 & 27 & 8 & 10 & 10 & 123 \\
\hline
\end{tabular}




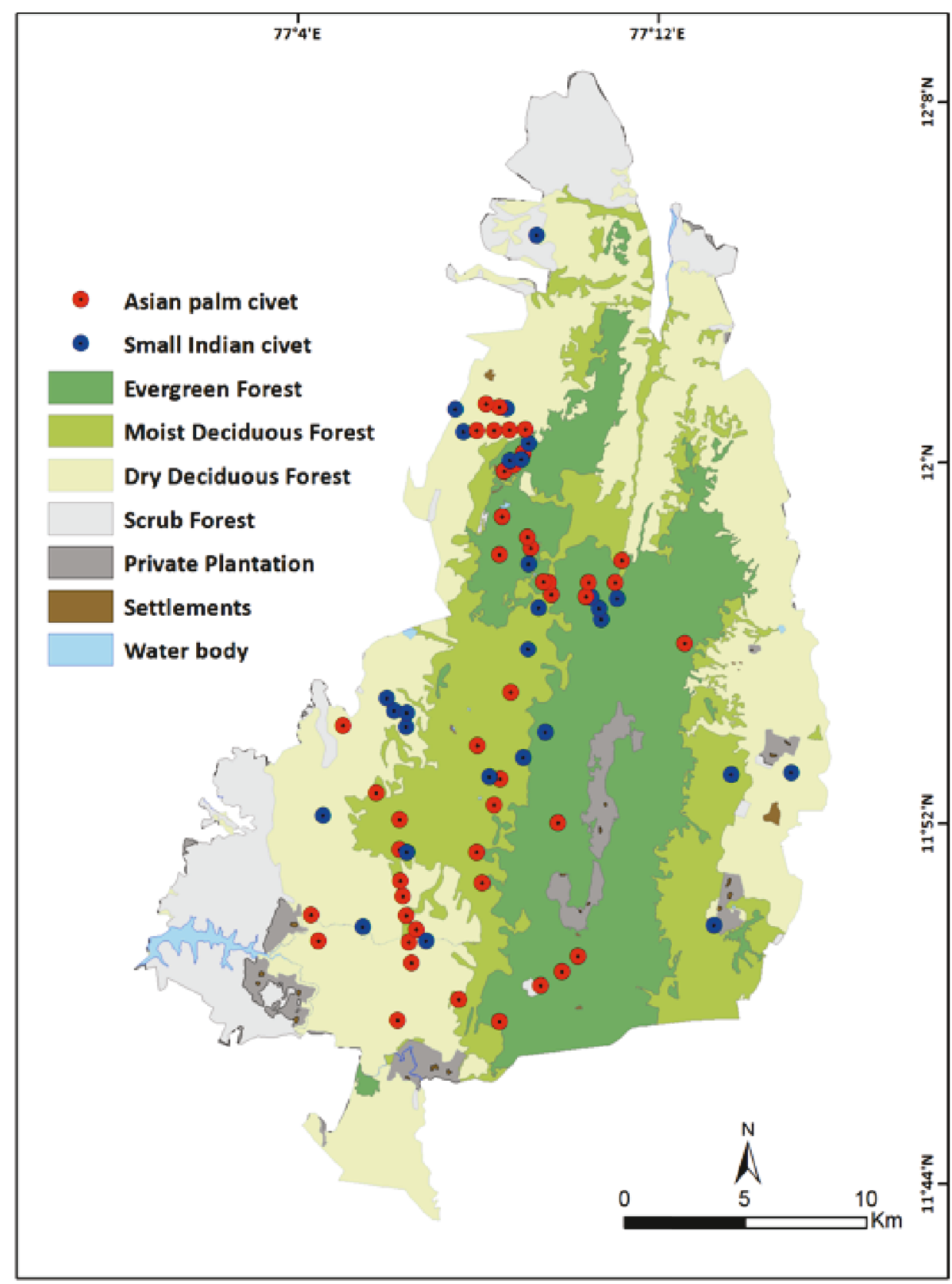

Figure 2. Detections of civets in BRT

on the home range of the species. The size of home range of many of the species included in the present study largely varies between 4-65 ha (65ha for the Small Indian Civet: Kumar \& Umapathy (1999); 14.1ha for the Asian Palm Civet: Joshi et al. (1995); 3.4-15 ha for the Common Mongoose: Kumar \& Umapathy (1999)). The number of traps deployed during the present study and the overall camera trap hours/nights were not sufficient to capture the existing species and their abundance. Though the capture rate was poor, the camera trap technique proved to be an efficient method to capture most of the species occurring in BRT. The overall sight records from all the methods provided an understanding of the occurrence and habitat preference of small carnivores in the park, and further it clearly showed that they certainly occurred relatively more in number than the depicted capture rate by camera traps.

Though the presence of the Brown Palm Civet Paradoxurus jerdoni was not confirmed and even the nominal distribution range is not projected for BRT, a suitable habitat for the species seems to exist in BRT. Descriptions of a similar animal by the local people match 


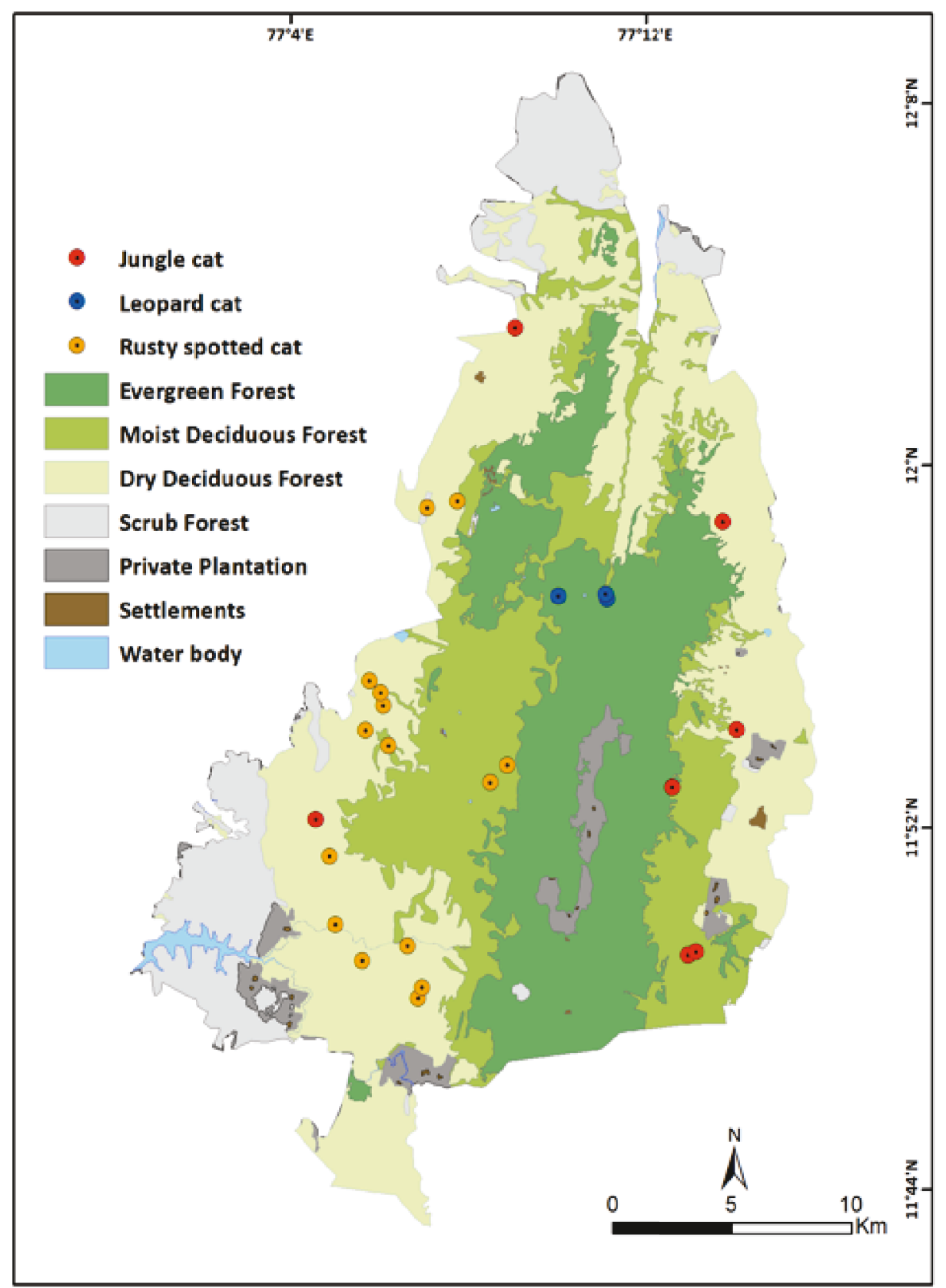

Figure 3. Detections of small cats in BRT

with it, and hence the occurrence of the Brown Palm Civet cannot be ruled out. However, there are no proper sight records of the Brown Palm Civet from BRT and this may require more systematic investigation, especially around private coffee plantations and surrounding evergreen forests in the higher altitude of BRT. The Smooth-coated Otter needs separate investigation in expected areas.

The Asian Palm Civet is known to occur in various forest types varying from thick woody areas to urban habitat (Kumara \& Singh 2007). Since the species is mostly arboreal and requires wooded forest or elevated construction, it was sighted in all the forest types except in the scrub forests. The Asian Palm Civet may be most abundant species compared to the other small carnivore species in the BRT. A similar observation was reported for the state of Karnataka (Kumara \& Singh 2007).

During the study, the Jungle Cat was recorded only from disturbed forests or marginal forests with open canopy of mid and low elevations of BRT. On the other hand, the Leopard Cat, which is a forest dwelling animal, was recorded only from the relatively wet forests with denser vegetation. The Rusty-spotted Cat is known 


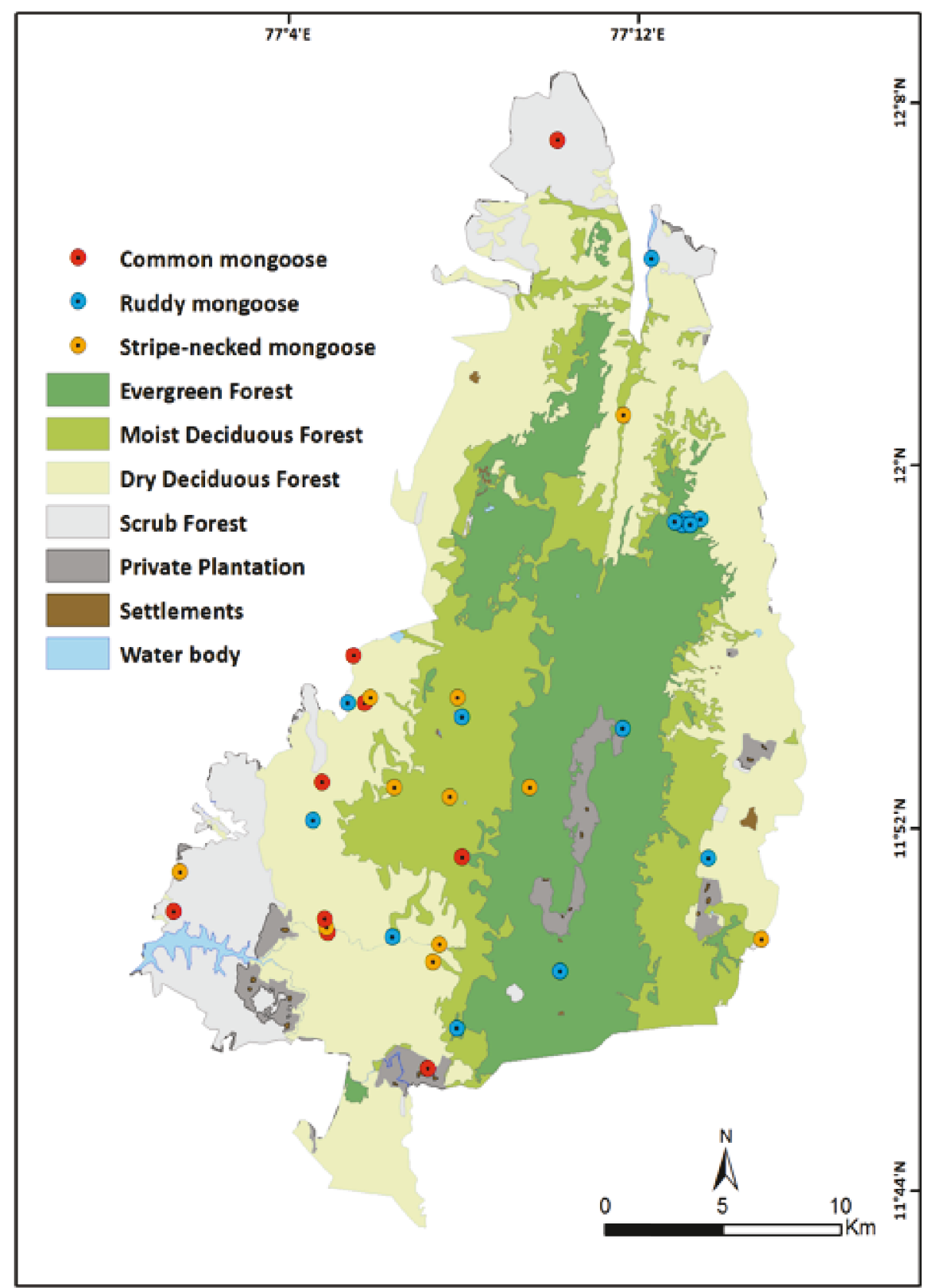

Figure 4. Detections of mongooses in BRT

to inhabit a variety of habitats varying from villages, agriculture land and deciduous forests (Kumara \& Singh 2007), and was recorded mostly in the mid and low elevation forests of BRT. The 13 sight records of this species in BRT are more than the sightings reported from many other parks in the country, which could probably be attributed to less exploration and sampling effort for this species. Though all the three small cats show wide distribution range, each species might prefer specific vegetation types. Though these sight records projects the habitat preference by each species, more robust data and exploration is required to confirm the same.

Compared to other species, the total detections of the mongoose species were relatively less. Intensive camera trapping might give more reliable data than any other method since these animals can be easily missed during transect walks. The probable reason for more sightings of the Ruddy Mongoose in evergreen forests and moist deciduous forest may be due to the presence of more rocky areas at the transition of dry forests with wet forests on the slopes.

The forests of BRT, which range from shola forests at 
higher altitude to open scrub forests at lower altitude provide a unique opportunity to study the habitat preference and ecology of small carnivore species. The Rusty-spotted Cat is one of the lesser-known small cats, was encountered more often than other species of small cats in the area, and hence adds conservation value to the area. The management requires retaining of all the forests types as such without much alteration, since each forest type is unique in its own way for its species.

\section{REFERENCES}

Anonymous (2006). Fauna of Biligiri Rangaswamy Wildlife Sanctuary. Conservation Area Series 27. Zoological Survey of India, Kolkata.

Aravind, N.A., R. Dinesh \& P.S. Madhusudan (2001). Additions to the birds of Biligiri Rangaswamy Temple Wildlife Sanctuary, Western Ghats, India. Zoos' Print Journal 16(7): 541-547; http://dx.doi.org/10.11609/ JoTT.ZPJ.16.7.541-7

Bawa, K.S., S. Lele, K.S. Murali \& B. Ganesan (1999). Extraction of nontimber forest products in Biligiri Rangan Hills, India: Monitoring a community-based project, pp. 89-102. In: Saterson, K., R. Margolius \& N. Salafsky (eds.). Measuring Conservation Impact: An Interdisciplinary Approach To Project Monitoring And Evaluation. Biodiversity Support Program. World Wildlife Fund, Inc. Washington D.C., USA.

Ganesan, R. \& R.S. Setty (2004). Regeneration of Amla, an important nontimber forest from south India. Conservation and Society 2: 365-375.

Ganeshaiah, K.N. \& R.U. Shankar (1998). BRT Sanctuary: a biogeographic bridge of the Deccan Plateau, pp. 4-6. In: Ganeshaiah, K.N. \& R.U. Shankar (eds.). Biligiri Rangaswamy Temple Wildlife Sanctuary: Natural history, Biodiversity and Conservation. Ashoka Trust for Research in Ecology and the Environment and Vivekananda Girijana Kalyanakendra, Bangalore, India.

Ganeshaiah, K.N., R.U. Shanker, K.S. Murali \& K.S. Bawa (1998). Extraction of non-timber forest products in the forests of Biligir Rangan Hills, India. 5. Influence of dispersal mode on species response to NTFP extraction. Economic Botany 52: 316-319.

Hegde, R., S. Suraprakash, L. Achot, S. Lele \& K.S. Bawa (1996). Extraction of non-timber forest products in the forests of Biligiri Rangan Hills, India. 1. Contribution to rural income. Economic Botany 50: 243-250.

Islam, Z. \& A.R. Rahmani (2004). Important Bird Areas in India: Priority Areas for Conservation. Bombay Natural History Society, Mumbai, BirdLife International, UK and Oxford University Press, Mumbai.

Joshi, A.R., J.L.D. Smith \& F.J. Cuthbert (1995). Influence of food distribution and predation pressure on spacing behavior in Palm Civets. Journal of Mammalogy 76: 1205-1212.

Karthikeyan, S., J.N. Prasad \& T.S. Srinivasa (1995). Yellow throated Bulbul Pycnonotus xantholaemus at Biligirirangana Hills, Karnataka. Journal of Bombay Natural History Society 92: 123-124.

Kelly, M.J. \& E.L Holub (2008). Camera trapping of carnivores: trap success among camera types and across species, and habitat selection by species, on Salt Pond Mountain, Giles County, Virginia. Northeastern Naturalists 15: 249-262; http://dx.doi.org/10.1656/10926194(2008)15[249:CTOCTS]2.0.CO;2

Kumar, A. \& G. Umapathy (1999). Home range and habitat use by Indian Grey Mongoose and Small Indian Civets in Nilgiri Biosphere Reserve, India, pp. 87-91. In: Hussain SA ed. ENVIS Bulletin: Wildlife and Protected Areas, mustelids, viverrids and herpestids of India, Wildlife Institute of India.

Kumara, H.N. \& M. Singh (2007). Small carnivores of Karnataka: Distribution and sight records. Journal of Bombay Natural History and Society 104: 153-160.

Kumara, H.N., M. Singh \& S. Kumar (2006). Distribution, habitat correlates and conservation of Slender Loris Loris lydekkerianus in Karnataka, India. International Journal of Primatology 27: 941-969.
Kumara, H.N., S. Rathnakumar, M.A. Kumar \& M. Singh (2012). Estimating Asian elephant Elephas maximus density through distance sampling in the tropical forests of Biligiri Rangaswamy Temple Tiger Reserve, India. Tropical Conservation Science 5: 163-172.

Kumara, H.N., S. Rathnakumar, R. Sasi \& M. Singh (2012). Conservation status of wild mammals in Biligiri Rangaswamy Temple Wild life Sanctuary, the Western Ghats, India. Current Science 103: 933-940.

Menon, V. (2003). A Field Guide to Indian Mammals. Dorling Kindersley (India) Pvt. Limited, 201pp.

Mudappa, D. (2001). Ecology of the Brown Palm Civet Paradoxurus jerdoni in the tropical rainforests of the Western Ghats, India. PhD Thesis. Bharathiar University, Coimbatore, India.

Mukherjee, S. (1989). Ecological separation of three sympatric carnivores in Keoladeo-Ghana National Park, Rajasthan, India. Dissertation submitted to the Saurashtra University, Rajkot in partial fulfillment of master's degree in Wildlife Science.

Mukherjee, S., S.P. Goyal, A.J.T. Johnsingh \& M.R.P.L. Pitman (2004). The importance of rodents in the diet of Jungle Cat (Felis chaus), Caracal (Caracal caracal) and Golden Jackal (Canis aureus) in Sariska Tiger Reserve, Rajasthan, India. Journal of Zoology 262: 405-411.

Murali, K.S., U. Shankar, R.U. Shanker, K.N. Ganeshaiah \& K.S. Bawa (1996). Extraction of non-timber forest products in the forests of the Biligiri Rangan Hills, India. 2. Impact of NTFP extraction on regeneration, population structure, and species composition. Economic Botany 50: 251-269.

Murali, K.S. \& R.S. Setty (2001). Effects of weeds Lantana camera and Chromelina odorata growth on the species diversity, regeneration and stem density of tree and shrub layer in BRT sanctuary. Current Science 80: 675-678.

Murali, K.S., R.S. Setty, K.N. Ganeshaiah \& R.U. Shankar (1998). Does forest type classification reflect spatial dynamics of vegetation? An analysis using GIS techniques. Current science 75: 220-227.

Nag, K. (2008). Assessing animal abundance from photographic capture data using an occupancy approach. MSc Thesis, submitted to Manipal University.

Prater, S.H. (1971). The Book of Indian Animals. 4th Impression. Bombay Natural History Society, Bombay, and Oxford University Press.

Ramesh, B.R. (1989). Flora of Biligirirangan Hills. PhD Thesis. Madras University, Madras, India.

Rajamani, N., D. Mudappa \& H.V. Rompaey (2003). Distribution and status of the Brown Palm Civet in the Western Ghats, south India. Small Carnivore Conservation 27: 6-11.

Setty, R.S., K.S. Bawa \& J. Bommaiah (2001). Participatory research monitoring for non-timber forest products in Biligiri Rangaswamy Temple Wildlife Sanctuary, Karnataka, India, pp. 85-88. In: Ganeshaiah, K.N., R.U. Shanker \& K.S. Bawa (eds.). Tropical Ecosystems: Structure, Diversity and Human Welfare. Oxford and IBH Publishing Co. Pvt. Ltd., New Delhi.

Shankar, U., K.S. Murali, R.U. Shanker, K.N. Ganeshaiah \& K.S. Bawa (1996). Extraction of non-timber forest products in the forests of Biligiri RanganHills, India. Productivity, extraction and prospects of sustainable harvest of Nelli (Amla) (Emblica officinalis). Economic Botany 50: 270-279.

Shanker, R.U., K.N. Ganeshaiah, M.N. Rao \& N.A. Aravind (2004). Ecological consequences of forest use-from genes to ecosystem: a case study in the Biligiri Ranganswamy Temple Wildlife Sanctuary, south India. Conservation and Society 2: 347-364.

Shanker, R.U., R. Hegde \& K.S. Bawa (1998). Extraction of non-timber forest products in the forests of Biligiri Rangan Hills, India. 6. Fuel wood pressure and management options. Economic Botany 52: 320-336.

Srinivasan, U. \& N.S. Prashanth (2005). Additions to the Avifauna of the Biligirirangans. Indian Birds 1(5): 104.

Srinivasan, U. \& N.S. Prashanth (2006). Preferential routes of bird dispersal to the Western Ghats in India: an explanation for the avifaunal peculiarities of the Biligirirangan Hills. Indian Birds 2(4): 114-119.

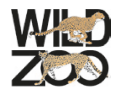

